\title{
REDESIGN PROMOTION STRATEGY OF ABC SENIOR LIVING IN WEST JAVA TO IMPROVE SALES OCCUPANCY - A QUALITATIVE RESEARCH
}

\author{
Shita Oktaviani Nurhikmah ${ }^{1}$, Sonny $^{2}$ \\ ${ }^{1}$ Faculty of business President University, Cikarang \\ Email: shitaoktaviani52@gmail.com \\ ${ }^{2}$ Faculty of business President University, Cikarang \\ Email: sonny@president.ac.id
}

Masuk : 17-04-2020, revisi: 21-04-2020, diterima untuk diterbitkan : 22-04-2020

\begin{abstract}
ABSTRAK
Penelitian ini menyoroti strategi desain ulang promosi untuk panti jompo ABC di Jawa Barat, untuk meningkatkan penjualan. Tujuan dari penelitian kualitatif ini adalah untuk menentukan masalah promosi saat ini, memeriksa persepsi konsumen, dan mendesain ulang strategi promosi untuk mencapai target. Dari penelitian ini, ditemukan bahwa tidak ada masalah signifikan dari konsumen dan konsumen potensial, terkait dengan layanan dan fasilitas. Dapat disimpulkan bahwa kegagalan mencapai target penjualan, karena strategi promosi tidak ditujukan untuk target pasar yang tepat. Perusahaan perlu mendesain ulang strategi promosi pada target yang tepat, dan dapat mencapai target yang ditentukan oleh Manajemen ABC.
\end{abstract}

Kata Kunci: Redesign Promotion strategy, senior living, hospitality

\begin{abstract}
This research highlights the redesign promotion strategy for ABC senior living in West Java, to improve sales occupancy. The objective of this qualitative research are to determine the current promotion problems, check the consumer perceptions, and redesign promotion strategy to achieve the target. From this study, it's found that there are no significant problems from consumers and potential consumers, related with service and facilities. It can be concluded that the failure to reach the sales target, because promotion strategy not aimed for the right target market. The company needs to redesign promotion strategy on the right target, and be able to achieve the target as determined by ABC Management.
\end{abstract}

Keywords : Redesign Promotion strategy, senior living, hospitality

\section{INTRODUCTION \\ Background}

Indonesia as a gateway between the east and the west continent trade, and listed in the top 5 by volume of foreign direct investments in Pacific Asia. One major industry in Indonesia is property industry. The increase of property industry has attracted and contributed in positive way to the national economic growth, of which many corporation and individual want to try their luck at property industry ( Fauzan, 2017).

One of related sector with property is hospitality industry. $\mathrm{ABC}$ is a senior living that located 50 $\mathrm{km}$ from Jakarta with luxury standard. $\mathrm{ABC}$ is comfortable resting place for the elderly, who want to get away from worldly problems, and relax for the rest of their lives. Problem arise when promotions that have been carried out can't achieved the target, and below their room capacities. The target of $\mathrm{ABC}$ management must be filled $50 \%$ or more. Below is table that shows room capacity and occupancy of $\mathrm{ABC}$ in the last 4 years. 
Table 1 : Total Room Capacity And OccupancyABC senior living, West Java Source : ABC senior living administration

\begin{tabular}{ccc}
\hline Year & Room Capacity & Average Occupancy \\
\hline 2020 & 44 & $15 \%$ \\
\hline 2019 & 44 & $10 \%$ \\
\hline 2018 & 44 & $10 \%$ \\
\hline 2017 & 44 & $8 \%$ \\
\hline
\end{tabular}

Second things that need to be reviewed, whether there are dissatisfaction from existing consumers, so the negative news spread and causes people to avoid for visiting. And the last point, researcher will redesign promotion strategy, and make $A B C$ senior living align to the right track.

\section{Research Objectives}

By writing this thesis, the researcher has objectives :

1. To determine the mistakes of current promotion strategies in $\mathrm{ABC}$ senior living

2. To determine the consumer perception of $A B C$ senior living

3. Redesign promotion strategies for $\mathrm{ABC}$ to achieve the target

\section{Significance of the Study}

This research will be significant to $\mathrm{ABC}$ senior living to increase its residence occupancy ; and also give recommendation of promotion to be applied effectively.

\section{Limitation}

This study is limited to $\mathrm{ABC}$ senior living in West Java. There are Five respondents supporting this research. Two respondents are residence of $\mathrm{ABC}$, two respondents are potential consumers, and one respondent is promotion manager. All respondents support information to complete this research.

\section{LITERATURE REVIEW}

\section{Hospitality}

Cerovic in Batinic (2013) defines "Hospitality is an economic activity which organizes, provides and meets the needs of guests for overnight stays, food and beverages." In other words, hospitality can be considered as a production and service industry. Preparing food and drink is under production industry while providing accommodation and serving prepared food and beverages are under service industry.

Morrison (2011) describe two groups of individuals in hospitality and travel promotion, to be specific the guest (consumers) and the host ( the indiciduals who work with hospitality and travel organization ). Managing this guest-host relationship is one of the key function in our industry; in fact, some say it is the most important.

\section{Promotion Strategy in Hospitality Industry}

The competition in hospitality industry requires the company to formulate a strategy which can adapt to the changes in the market. Usually, the goal is to identify opportunity to serve the market that is profitable and effective so it is difficult for another company to take up the opportunity without becoming losses. An hotelier that wants to achieve success needs to have a deep understanding of marketing, and how to combine various promotion elements such as the price, product promotion and distribution. 


\section{Segmentation, Targeting, Positioning (STP)}

Promotion strategy development covers frameworks as segmenting, targeting, and positioning (STP). In order to develop promotion strategy, Tarantino as quoted in Khan (2013) stated three components that should be clearly defined: "Segmentation or who can I sell my services to?" ; Targeting or Who I am going to sell my services to ? Positioning or How I am going to sell my services?".

The following figure describes the stages of STP implementation concept proposed quoted by DeSabro (2014) as modified from Kotler.

Figure 1: STP implementation concept

\begin{tabular}{|c|c|c|}
\hline $\begin{array}{c}\text { Market } \\
\text { Segmentation }\end{array}$ & $\begin{array}{c}\text { Market } \\
\text { Targeting }\end{array}$ & $\begin{array}{c}\text { Market } \\
\text { Positioning }\end{array}$ \\
\hline $\begin{array}{l}\text { 1. Identify basis } \\
\text { variables and } \\
\text { segment the } \\
\text { market } \\
\text { 2. Develop profiles } \\
\text { of resulting } \\
\text { segments }\end{array}$ & $\begin{array}{l}\text { 3. Evaluate } \\
\text { attractiveness for } \\
\text { each market } \\
\text { segment } \\
\text { 4. Select target } \\
\text { segment(s) }\end{array}$ & $\begin{array}{l}\text { 5. Identify positioning } \\
\text { concepts for each } \\
\text { target segment } \\
\text { 6. Select, develop, } \\
\text { and communicate } \\
\text { the selected } \\
\text { positioning } \\
\text { concept(s) }\end{array}$ \\
\hline
\end{tabular}

Nowadays, companies are in the era where they orientation to customer. Every company attempts to break down markets into some parts of the consumer groups and treat them based the same characteristics, that is called market segmentation as mentioned by Gretzner in Khan (2013).

\section{Niche Market}

According to Thilmany (2012)" niche markets consist of groups of consumers or market segments in larger marketplace who have similar demographic, purchasing behavior, and lifestyle characteristics". Shani \& Chalasani in Akbar et al (2017) defined "niche promotion as the process of carving out a small part of the market whose needs are not fulfilled". By specializing along market, consumers, product or promotion mix lines a firm can match the unique needs of the niche or that group. Dalgic \& Leeuw in Akbar et al (2017) consider a niche market to be a small market consisting of an individual consumers or a small group of consumers with similar characteristics and defined niche promotion as positioning into small, profitable homogenous market segment which have been ignored or neglected by others.

\section{Research Methodology}

The qualitative method usually gathered from written documents and through case studies. In this journal, researcher using qualitative ( Descriptive analysis) method with the approach is case study to analysis the practice and find out the problem of the less occupancy in ABC Senior Living, West Java. According to Crossman (2017) "methods of qualitative research include observation and immersion, interviews, open-ended surveys, focus groups, content analysis of visual and textual materials, and oral history. After having personally interviewed the respondents, the tape recorded data were transcribed. This is essential in order to assure that all information emerges and is found in the right context, and for the confirmability of data." 


\section{Data Collecting Technique}

The data collected was in qualitative nature. The type of data that was collected was primary data. The instrument used in collecting primary data was an interview guide.

\section{ANALYSIS AND DISCUSSION}

As explained in the literature review above, the qualitative concept used in this journal is the interview method. The interview contained questions that were directed to promotion manager (1 person), residents ( 2 persons) and potential consumers ( 2 persons).

The purposes to conduct interview with a marketing manager are to identify the existing promotional concept and its effectiveness in gaining consumers, as well as to find out things that need to be fixed or improved.

The purpose of an interview with residents and potential customers is to find out whether maximum service and facilities are already provided, in accordance to the price they paid.

Here are the results of the interview.

\section{Interview process with marketing manager (respondent 01)}

Researcher Who are the specific target market of ABC senior living ?

Respondent 1 We focused on elderly aged 65 and above, come from premium class in West Java

Researcher Can you tell me the price list of ABC senior living ?

Respondent 1 Sorry, I can't. It parts of company confidential.

We can share the price list to our potential consumers only. But I can tell you type of payment. You can pay per week, per month, per year, or lifetime payment. Lifetime payment means, $A B C$ senior living will serve you for the rest of your life.

Researcher What kind of promotion that held by ABC in the last 4 years ?

Respondent 1 We are doing promotions by online and offline regularly.

For online promotion, we have a facebook and instagram account which is updated once a month. For offline, we promote on Info Bogor, Info Depok, and Info Bekasi. We also distribute brochures to several luxury housing units in Bodetabek (except Jakarta), whose their parents may be our potential consumers. There are no additional fees, just need permission from the head of neighbourhood (ketua RT). We also put banners around our location.

Researcher Why Jakarta is not included in this promotion?

Respondent 1 We do it like guerrilla warfare. Step by step.

Attacking areas outside Jakarta first, then after everything has been managed,, Jakarta will be the last destination.

Researcher How did you find the luxury housing area around Bodetabek ?

Respondent 1 I search it manually on internet.

If the average price of housing are IDR 5 billion and above, then I will take the cluster / area as the target market.

Researcher How do you know that there are parents who live in these luxury housing?

Respondent 1 I don't know. We just distribute brochures to all houses in the area 
Researcher What kind of events that held by $\mathrm{ABC}$ in the last 4 years ?

Respondent 1 We created coloring events for kindergarten at weekend, on 2016 and 2017. On 2018, ABC created Japanese cultural event, collaborated with one of Japanese company in Bekasi. Both events attract crowds, several consumers around Jabodetabek visited us. The events held in parking area and first floor of $A B C$.

Researcher How many consumers that you get from these local events in the 4 years?

Respondent 1 Honestly, we got zero.

Management's vision for longterm is awareness, so potential consumers around Jabodetabek know about ABC senior living. After they visit us, see the building, facilities, and service by themself, will be easier for us to sell.

Researcher How to measure the performance of your activities every month ?

Respondent 1 We are still on the good performance so far.

Our monthly target are looking for 5-8 luxurious housing in Bodetabek, and then distribute flyers to all the houses in it. This is the measurement we used in the last 4 years.

Researcher Are you sure the existing strategy has been on the right track ?

Respondent 1 Honestly, the result not as we expected.

We open for all inputs, which can align us to the right track. One constraint from internal factor is limited budgets for promotion, so the maximum that we can do are promote on magazines, distribute brochures, and put banners in several areas. Larger events such as cultural events, we collaborated with sponsors, so there are no additional costs from us.

\section{Interview process with residents and potential residents (respondent $02,03,04$ and 05 )}

The interview with the second to fifth respondent aims to measure how satisfied they are with the services and facilities they have seen and felt so far. It's a possibility that maybe the marketing strategy is correct, but because there is dissatisfaction from existing consumers, it can be a negative issue that causes potential consumers to avoid it.

The interview process was conducted privately with each respondent, with the same questions. There are 4 questions asked :

1. What is your opinion about price of $\mathrm{ABC}$ senior living?

2. What is your opinion about the facilities provided by ABC senior living?

3 . What is your opinion about the service provided by $\mathrm{ABC}$ senior living?

4. What is your opinion about the daily programs provided by $\mathrm{ABC}$ senior living?

Their answers are quite varied, depending on their perceptions and experiences. If summarized briefly, it can be seen in the following table : 
Tabel 2. Summary of perceptions from respondents and potential respondents Related with their experiences in ABC senior living

Source : direct interview

\begin{tabular}{ccccc}
\hline \multirow{2}{*}{ Perception } & \multicolumn{4}{c}{ Consumers } \\
\cline { 2 - 5 } & $\begin{array}{c}\text { Respondent 2 } \\
\text { ( Resident })\end{array}$ & $\begin{array}{l}\text { Respondent 3 } \\
\text { ( Resident })\end{array}$ & $\begin{array}{c}\text { Respondent 4 } \\
\text { ( Potential } \\
\text { customer ) }\end{array}$ & $\begin{array}{c}\text { Respondent 5 } \\
\text { (Potential } \\
\text { customer ) }\end{array}$ \\
\hline Price & $\begin{array}{c}\text { High for } \\
\text { ordinary (-) }\end{array}$ & $\begin{array}{c}\text { Reasonable } \\
(+)\end{array}$ & $\begin{array}{c}\text { High for } \\
\text { ordinary(-) }\end{array}$ & $\begin{array}{c}\text { High for } \\
\text { ordinary(-) }\end{array}$ \\
\hline Facility & $\begin{array}{c}\text { Good enough } \\
(++)\end{array}$ & $\begin{array}{c}\text { Good } \\
(+)\end{array}$ & $\begin{array}{c}\text { Very good } \\
(+++)\end{array}$ & $\begin{array}{c}\text { Very Good } \\
(+++)\end{array}$ \\
\hline Service & Good & Good & Good & $\begin{array}{c}\text { Good } \\
(+)\end{array}$ \\
\hline Program & Enough & Good & Pretty good & Good \\
& $(+)$ & $(+)$ & $(++)$ & $(+)$ \\
\hline
\end{tabular}

From the previous table above, it can be seen that the majority of respondents always give positive feedback to these four questions. there are only two negative answers from potential consumers, regarding prices that are higher, compared to similar products. The price issue is also not a big problem, because target market of $\mathrm{ABC}$ is premium class.

\section{Analysis from interview with marketing manager (respondent 01)}

From the interview with the promotion manager, there are some mistakes that need to be fixed, which are as follows :

1. ABC management tried to find consumers from premium class in Bodetabek, then to Jakarta. This is actually reversed, because most premium consumers stay in Jakarta.

2. Performance measurements should be calculated from the number of consumers gained, not from how much job has been done

3. Events that have been held in the past 4 years can only attracting crowds, but not attracting potential consumers to come. Coloring events that focus on kindergarten, or cultural events that focus on young people.

4. Limited promotional budget cannot be used as an excuse; there are still many ways to achieve the target with limited budget.

\section{Redesign promotion strategy}

Because Jakarta is the top priority in finding consumers from premium class (comparing with areas outside Jakarta), then first we have to know where it is located. The location of premium class in Jakarta, can be seen from the price of the lands (price of land per $\mathrm{m}^{2}$ ), in the following figure. 


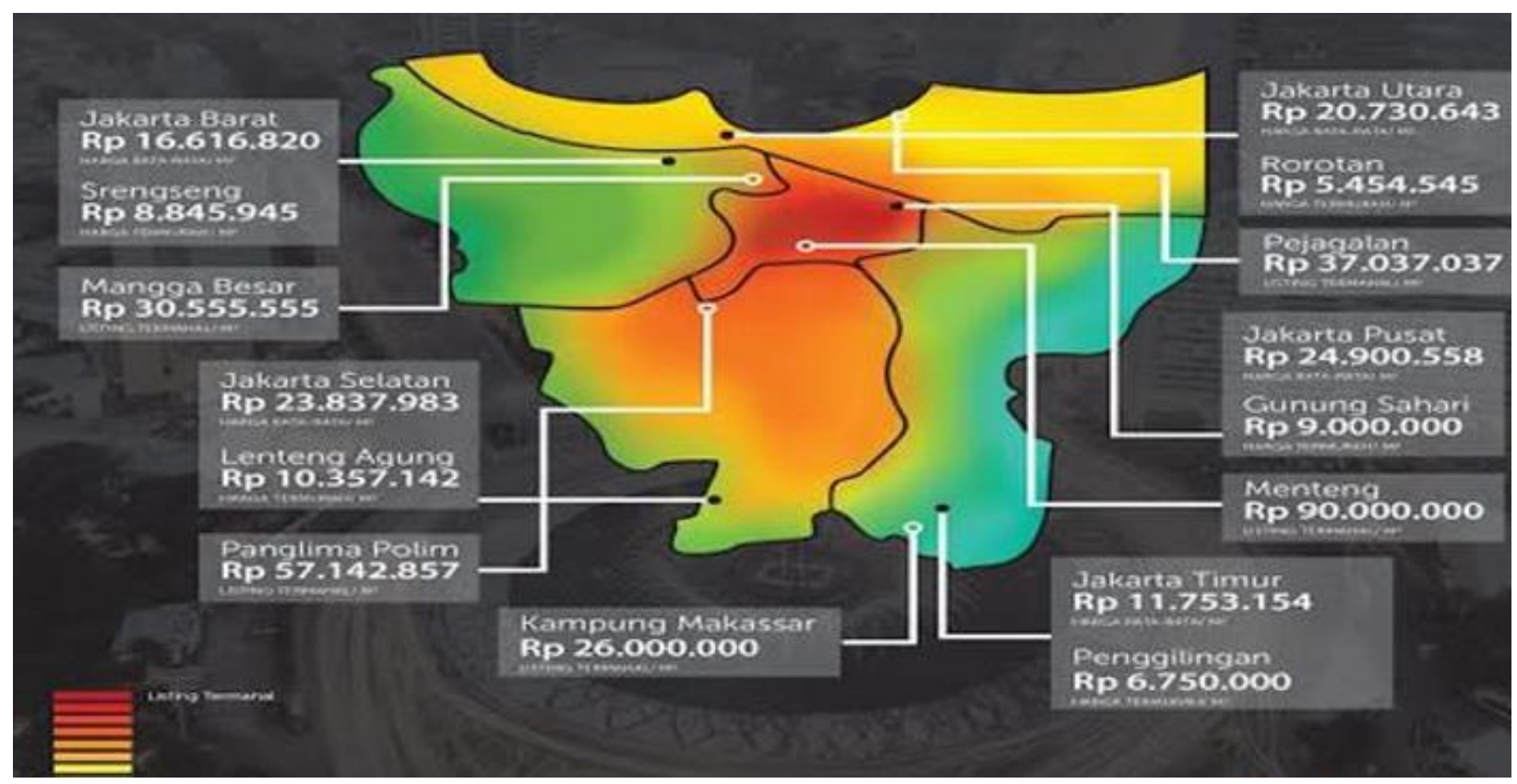

Picture 1 : The cheapest and most expensive area in jakarta.

Source : http://bisnis.liputan6.com/read/2172521/ini-daerah-termurah-dan-termahal-belihunian-di-jakarta

Based on map about the most expensive land in Jakarta in figure 1, here are 6 steps to do 1. Identify basis variables and segment the market

From the picture above, we can see mapping of land prices more clearly, it's easier to choose premium area, compared to previously promotion that just guessing. It is not necessary covered all Jakarta at the same time, but divided into several periods, and 5 areas covered per period. If ranked from the most expensives, there are 5 areas that must be prioritized : Menteng, Panglima Polim, Senopati, South Jakarta (Kemang and surrounding areas), Kelapa Gading, and Pluit. Central Jakarta and Mangga Besar also included in expensive areas, but not counted here, because the majority of the area used for commercial areas, rather than residences. $\mathrm{ABC}$ management should covered around $5 \mathrm{~km}$ from these premium areas. After these 5 areas have been tracked and get a number of consumers, then continue to the second priority area in the following year such as Puri Indah, Pondok Indah, Pantai Indah Kapuk, etc.

\section{Develop profiles of resulting segments}

On these five areas, it is necessary to separate them into smaller areas, by find specific clusters or apartments. It will be easier to track potential consumers in those specific area. Beside tracking on location, marketing team also needs to do promotions through local magazines in these areas, such as Info Gading, Info Pluit, Kemang Buzz, and Info Kebayoran.

\section{Evaluate attractiveness for each market segments}

After the specific clusters or apartments were known precisely, $\mathrm{ABC}$ management needs to collaborate with several appropriate parties / sponsors. ABC will hold several events that match with target markets, such as regular taichi exercises, yoga exercises, heart exercises, healthy seminars in old age, golden memory music events, etc.

In the middle of the event, the promotion team needs to do an intercepts with a company profile video / short speech about ABC senior living. After completing the event, the promotion team needs to do personal selling one by one to the event participants. Very rarely consumers want to 
buy directly for products like senior living, normally they need to think and consult with their families or children for a while. The most important thing is ABC captured their database, so it's easy to contact them later.

\section{Select target segments}

One week after the event, the marketing team needs to call these potential consumers regularly. It is also necessary to talk with their children or family, who become the decision makers. For some of them that show positive response, the marketing team need to talk seriously, by coming to his / her house.

5. Select, develop, and communicate the selected positioning concepts

$\mathrm{ABC}$ senior living needs to hold an open house every weekend, so potential consumers who might know about $\mathrm{ABC}$ from magazines or other info, can come right away. $\mathrm{ABC}$ also provides round-trip pickup, for consumers who register to attend from these 5 areas. Potential consumers who had previously been seriously talked to with their families, were also scheduled to attend the open house. In this open house the marketing team will show examples of rooms to be occupied, facilities provided, small clinic, and the quality of services provided.

The quality of $\mathrm{ABC}$ senior living is similar like a five-star hotel, so the services provided to consumers are also highly customized, tailored to the customer needs. For example, there are consumers who need to take certain drugs three times a day, need to visit certain doctors once a week, need to back to families once a month, all can be adjusted.

\section{Capture the target market}

From the previous explanation above, $\mathrm{ABC}$ management misinterprets performance at work. Performance means the results that have been obtained, not how much the marketing team has worked. If the marketing team feels they have worked hard, but the result is zero, then it means the performance is bad.

$\mathrm{ABC}$ management needs to set clear targets for each marketing activity. Researchers suggest that from every area tracked above, each area must obtain 3-5 potential consumers who are willing to become residents of $\mathrm{ABC}$ Senior Living. This number is not too difficult, because from each area there are dozens of potential consumers that can be captured. But on the other hand, this is also not too easy, because there needs to be deep thought from the family, before leaving his parents there.

From a simple calculation, if in $1^{\text {st }}$ period there are 5 areas, and each area is required to get 3-5 consumers, then there are 15-25 potential consumers that must be converted into residents from these 5 areas. It means around $34 \%-56 \%$ of the total capacity of 44 rooms.

To maximize occupancy up to $100 \%$, the marketing team needs to do the same thing in on $2^{\text {nd }}$ period, $3^{\text {rd }}$ period, etc.

\section{CONCLUSION AND RECOMMENDATION}

\section{Conclusion}

1. ABC senior living is a comfortable resting place for the elderly, located $50 \mathrm{~km}$ from Jakarta. Problem arise when promotions that have been carried out can't achieved the target, and below their room capacities. ABC management tried to find consumers from premium class in Bodetabek, then to Jakarta. This is reversed, Jakarta should become the priority in find consumer from premium class. 
2. The respondents and potential consumers give positive feedback for service and facilities, it means there are no problems with the quality of $\mathrm{ABC}$ senior living.

3. ABC management needs to redesign promotion strategy for achieve the target. Jakarta become the top priority in finding consumers from premium class

4. ABC management needs to set clear targets for each marketing activity. Researchers suggest that from every area tracked, each area must obtain 3-5 potential consumers who are willing to become residents of ABC Senior Living

\section{Recommendation}

1. ABC management needs to be smarter in assessing the current strategy. If within a certain period does not provide targeted results, need to change it immediately. Don't wait too long, like before.

2. ABC management needs to create a good relationship with potential consumers. Even they are not buying yet, they can provide recommendations to their colleagues.

\section{REFERENCES}

Damm, Sven (2011). Event Management: How to Apply Best Practices to Small Scale Events. First Edition. Hamburg : Dimplomica Verlag.

Kotler. P., Keller.K. L., Agnihotri. P. Y., and Haque. E. U (2010). Principles of Promotion South Asian Perspective.13th edition. India: Pearson edu.

Levential,Barry (2016).Geodemographics for marketers : using location analysis for research and Promotion. First Edition. London: Kogan Page.

Morrison, Alastair M (2011).Hospitality \& Travel Promotion. Fourth edition. New York: Delmar cengage learning.

Akbar et al (2017). The Niche Promotion Strategy Constructs (Elements) and its Characteristics A Review of the Relevant Literature.Galore International Journal of Applied Sciences and Humanities. Vol(1).P 73-80.

A. Antczak and B.A. Sypniewska (2017). Personal Selling in the Service Sector as One Promotion Promotional Too.Cross-Cultural Personal Selling. P35-56.

Al-debi, Hamed abdulnabi (2014).The Impact Of Services Promotion Mix 7P's In Competitive Advantage To Five Stars Hotel - Case Study Amman, Jordan. The Clute Institute International Academic Conference Orlando. P 39-48.

Batinic, sc. Ivica (2013). Current Trends In Hospitality Industry. Journal of Process Management-New Technologies, International.Vol(1).No.4.

Chaharsoughi,Shahriar (2011). The Affect Of Sales Promotion On Consumer Interest To Purchase In IKCO Automotive Company. Journal of Knowledge Management, Economics and Information Technology. Vol (1). P 1-3.

DeSarbo, Wayne S. Simon J. Blanchard A. Selin Atalay (2015). A New Spatial Classification Methodology for Simultaneous Segmentation, Targeting, and Positioning (STP Analysis) for Promotion Research. Review of Promotion Research. Vol (5). P 75-103.

Fajarini,S,A (2013). "Pengaruh Event Promotion dan Promosi terhadap Keputusan Pembelian pada Tenant di Lippo Malls Bandung". NIM. 21209042, Perpustakaan UNIKOM.Indonesia

Järvenpää, sanni (2015). Event Promotion Case RESTO 2015 Event (Skripsi). Finland : School of Tourism and Hospitality Management Degree Programme in Tourism Bachelor of Hospitality Management. 
Jha, S.M (2010). Hotel promotion. New Delhi: Himalaya Publishing House.

Kartinisari, mursalini (2015) .Pengaruh Media Iklan (Above The Line \& Below The Line) Produk Indihome Fiber Terhadap Keputusan Pembelian (Studi Kasus di Bandung Kota). Indonesia.

Khan, Tahsina (2013). STP strategy for New Product Launch-a Work in Progress. International Journal of Business and Management Invention.Vol(2). P 56-65

Larseen,Nynne (2010). Market Segmentation - A framework for determining the right target consumers (Thesis). Aarhus School of Business.

Loekito, Michael et al (2014). Analisa Pengaruh Promotion Mix (7p) Terhadap Keputusan Pembelian Di Folks! Coffee Shop And Tea House surabaya. Surabaya. Management Perhotelan, Universitas Kristen Petra.

Mahsa Familmaleki,et (2015). Analyzing The Impact Of Promotion Mix On Consumer's Purchase Decision. Advanced Social Humanities and Management 2. Vol(1). P 72-81.

Marcellina, Jesse (2017 ). Pengaruh Promotion Mix (7p) Terhadap Keputusan Pembelihan Pada Guest House Di Surabaya ( Skripsi ). Surabaya: Program Manajemen Perhotelan, Fakultas Ekonomi Universitas Kristen Petra.

Meo,Adeel et al (2014). The Impact of Promotional Tools on Sales Promotion. Journal of Public Administration and Governance. $\operatorname{Vol}(4)$.No. 2.

Omotayo, Oyeniyi (2011). Sales Promotion and Consumer Loyalty: A Study of Nigerian Tecommunication Industry. Journal of Competitiveness. Vol (3).

Owomoyela, S.K, Olasunkanmi, O., Oyeniyi, K.O (2013). Investigating the impact of promotion mix elements on consumer loyalty: an empirical study on negerian breweries PLC. Interdisciplinary journal of contemporary research in business. Vol(4). No.11.

Parrish, E (2010). Retailers ${ }^{e e}$ Use of Niche Promotion in Product Development. Journal of Fashion Promotion and Management. Vol(4). P 546-561.

Sukmana, yoga (2017). BPS: ini lima sektor yang catatat pertumbuhan tertinggi sepanjang 2016. Retreive from https://ekonomi.kompas.com/read/2017/02/06/ 133000826/bps.ini.lima.sektor.yang.catat.pertumbuhan.tertinggi.sepanjang.2016.

Arianti, Fiki. (2015). Ini Daerah Termurah dan Termahal Beli Hunian di Jakarta. Retreive from http://www.liputan6.com/bisnis/read/2172521/ini-daerah-termurah-dan-termahal-belihunian-di-jakarta

Fauzan, Ahmad. (2017). Indonesia Property outlook 2017: hotel sector. Retreive from https://www.linkedin.com/pulse/indonesia-property-outlook-2017-hotel-sector-ahmad$\underline{\text { fauzan }}$

Jacobson et al (2011) .The Impact of Senior Centers and Geriatric Healthcare Policy.http://www.ipa.udel.edu/healthpolicy/srcenters/FactSheet1.pdf. 